Abstracta Iranica Abstracta Iranica

Revue bibliographique pour le domaine irano-aryen

Volume 29 | 2008

Comptes rendus des publications de 2006

\title{
Warring souls: youth, media, and martyrdom in post- revolution Iran. Duke University Press, 2006, 290 p.
}

\section{Anicée Van Engeland}

\section{(2) OpenEdition}

1 Journals

Édition électronique

URL : http://journals.openedition.org/abstractairanica/32712

DOI : 10.4000/abstractairanica.32712

ISSN : 1961-960X

\section{Éditeur :}

CNRS (UMR 7528 Mondes iraniens et indiens), Éditions de l'IFRI

\section{Édition imprimée}

Date de publication : 15 mai 2008

ISSN : 0240-8910

\section{Référence électronique}

Anicée Van Engeland, «Warring souls: youth, media, and martyrdom in post-revolution Iran. Duke University Press, 2006, 290 p. », Abstracta Iranica [En ligne], Volume 29 | 2008, document 388, mis en ligne le 15 septembre 2008, consulté le 26 septembre 2020. URL : http://journals.openedition.org/ abstractairanica/32712 ; DOI : https://doi.org/10.4000/abstractairanica.32712

Ce document a été généré automatiquement le 26 septembre 2020.

Tous droits réservés 


\title{
Warring souls: youth, media, and martyrdom in post-revolution Iran. Duke University Press, 2006, 290 p.
}

\author{
Anicée Van Engeland
}

1 Dans ce livre, Varzi analyse la culture iranienne et l'application créative des théories occidentales qui forgent le caractère de l'Iran aujourd'hui. Elle analyse comment la culture iranienne s'accommode des imports venus de l'Occident et comment la société s'adapte à ces imports. Cette étude est essentielle car elle fournit une analyse de la jeunesse en Iran et de son intégration de la culture occidentale à la culture iranienne déjà très riche. Varzi étudie l'impact politique de ces changements.

INDEX

Thèmes : 13.1. Iran

\section{AUTEURS}

ANICÉE VAN ENGELAND

European University Institute - Florence 